\title{
ZANIKLÁ STŘEDOVĚKÁ VESNICE HABŘINKA U HOŘINĚVSI (OKRES HRADEC KRÁLOVÉ). ANALÝZA A INTERPRETACE POVRCHOVÝCH SBĚRŮ A GEOFYZIKÁLNÍHO MĚŘENÍ
}

\author{
PAVEL DRNOVSKÝ - PETER MILO - TOMÁŠ TENCER
}

\begin{abstract}
Abstrakt: Přispěvek se věnuje zaniklé středověké vesnici Habřinka, jež se nacházela nedaleko Hořiněvsi u Hradce Králové ve východních Čechách. Lokalita je v písemných pramenech zmiňována od průběhu 15. století až do závéru první poloviny 17. století. Prostor zaniklé vsi byl zkoumán pomocí povrchových sbèrů a geofyzikálního měření. Keramické nálezy umožňuji posunout dobu vzniku vesnice na přelom 13. a 14. století. Na základě prostorové distribuce keramiky a magnetometrického měřeni jsme schopni vymezit areál zaniklé vsi a vyjádřit se k jeji vnitřni struktuře.
\end{abstract}

Kličcová slova: osidlení - zaniklá vesnice - vrcholný středověk - povrchový sběr - geofyzikální průzkum.

The deserted medieval village of Habřinka, near Hořiněves (Hradec Králové district). Analysis and interpretation of surface collecting and geophysical measurements

\begin{abstract}
This contribution is devoted to the deserted village of Habrinka, once located not far from Hořinèves near Hradec Králové, eastern Bohemia. In written sources the site is mentioned from the 15th century until the end of the first half of the 17th century. The area of the former village was surveyed by means of surface collecting and geophysical measurements. The finds of pottery enabled to shift the period when the village was established to the late 13th century - early 14th century. Thanks to the spatial distribution of finds and magnetometric measurements it is possible to demarcate the area of the deserted village and to determine its internal structure.
\end{abstract}

Key words: settlement - deserted village - high Middle Ages - surface collecting - geophysical survey.

\section{1 Úvod}

Studium věnující se (zaniklým) vesnicím vrcholného a raně novověkého období tvoří od druhé poloviny minulého století nedílnou součást bádání dějin osídlení. Ve střední Evropě existují regiony s dlouhodobou tradicí výzkumu založenou na individuálních osobnostech a na několika generacích badatelských týmů. Centrem zájmu se staly zejména lokality s dochovanými terénními relikty situované v lesním prostředí umožňující topografický průzkum. Zaniklé vsi nacházející se v zemědělsky využívaném polním prostředí se tak dostaly mimo hlavní záběr archeologů. Jedním z takových regionů, ve kterém prozatím postrádáme přesvědčivé relikty zaniklých vsí, jsou severovýchodní Čechy. Pro studium vsí bez dochovaných nadzemních reliktů je důležitá aplikace nedestruktivních metod - povrchových sběrů a geofyzikální průzkum. Přesto zaniklé vsi vrcholně středověkého a raně novověkého stáŕí nepatří $\mathrm{k}$ často geofyzikálně zkoumaným lokalitám. Uskutečněný průzkum tak můžeme v českých podmínkách označit za jeden z prvních výzkumů, který zaznamenal podstatnou část osídleného areálu, přičemž umožnil vyjádřit se $\mathrm{k}$ rozsahu a struktuře zaniklé vsi.

\section{Zkoumaná lokalita ve výpovědi písemných pramenů}

Vesnici Habřinku lze v písemných pramenech spolehlivě identifikovat až v pohusitském období. Obtíž panuje v odlišení v dobových písemnostech s blízkou vsí Habřinou (3 km východně), která je v pramenech připomínaná od roku 1357 (LC I/1,29). Chybné záměny se tak např́íklad dopustil již F. Roubík, který první zmínku o Habřince určuje právě k roku 1357 (Roubík 1959, 103). Na základě písemných pramenů lze dovodit, že v předhusitském období byla Habřinka a okolní blízké vesnice součástí majetků opatovického kláštera. Ze sousední vsi Hořiněvsi pocházel 
jeden z opatů kláštera, známý kronikář Neplach, lze tedy pouze spekulovat, zda se Habřinka nedostala do majetků kláštera jako donace. V roce 1421 byl klášter vypálen Divišem Bořkem z Miletínka, který se zmocnil i jeho statků (Sedláček 1882, 54). V listináři Viléma z Pernštejna je zaznamenáno, že císař Zikmund stvrdil Diviši Bořkovi držbu Kunětické hory a vesnic kláštera opatovického (AČ 16, 202 č. 184). V roce 1437 je pak výslovně zmíněna Habřinka ${ }^{1}$ jako ves náležící kdysi ke klášteru v Opatovicích nad Labem, a to při př́ležitosti zápisu zboží Aleši Vřeštovskému z Rýzmburka (AČ 1, 540 č. 244). Společně s Habřinkou jsou jako bývalé majetky kláštera zmíněny i blízké vsi Benátky, Máslojedy a Račice. Habřinka se posléze dostala do držení Buriana z Lípy a později jako královská zástava roku 1468 bratrům Petru a Benešovi Kdulínci z Ostromíře (AČ 4, 18 č. 7). Po smrti Jiř́ho z Poděbrad se kunětického panství ujímá jeho syn Jindřich starší z Minsterberka (Šandera 2016, 74), tehdy je opět zmíněna Habřinka a okolní vsi (Benátky, Máslojedy, Račice) náležející pod Kunětickou horu (AČ 16, 203 č. 184). Jindřich však musel vzhledem k své finanční situaci části svých držav zastavovat, až v roce 1491 prodal kunětické panství Vilémovi z Pernštejna (Sedláček 1882, 57). Vilém pak o dva roky později tyto zástavy, jejichž součástí byla i Habřinka, vyplatil od Zikmunda Kurcbacha z Vítkova (AČ 4, 197-198, 200 č. 24, 26).

Z doby, kdy byla Habřinka součástí pernštejnských východočeských držav, se dochoval v rámci pardubického urbáře $\mathrm{z}$ roku 1521 i její popis (AČ 17, 437). Uvedeno je pět hospodářù ${ }^{2}$ a způsob plateb. V roce 1547 byla Habřinka společně s dalšími vesnicemi (Benátky, Máslojedy, Račice) koupena Vilémem Trčkou z Lípy a přičleněna ke smiřickému panství (Sedláček 1883, 227). Po zbytek své existence pak Habřinka zůstala jeho součástí. Až do roku 1636 bylo dominium v držení Trčků z Lípy. Po násilné smrti Adama Erdmana Trčky z Lípy v roce 1634 v Chebu připadlo o dva roky později panství generálu Matyáši Gallasovi, který jej držel až do své smrti v roce 1647 (Rebitsch 2013, 224-225). Poté statky přešly do rukou jeho nezletilých synů Antonína Pankráce Rudolfa a Františka Ferdinanda Ignáce z Gallasu (Chalupa 1958, 197).

Ves Habřinka se celkem čtyřikrát dostala do zápisů urbářů smiřického panství z let 1588 , 1619, 1642 a $1655 .{ }^{3}$ Díky nim si lze vytvořit představu o velikosti Habřinky a sousedních vsí. $\mathrm{K}$ roku 1588 jsou uvedeni čtyři usedlí ${ }^{4}$ a k roku 1619 pak šest hospodářů. ${ }^{5} \mathrm{~V}$ následujícím urbáři, který pochází patrně z roku 1642, se zřetelně projevily důsledky válečných událostí, jež zasáhly oblast mezi Hradcem Králové a Jaroměří, nebot' jsou zde uvedena pouze tři jména. ${ }^{6}$ V roce 1628 na smiřickém panství vypuklo rozsáhlé poddanské povstání, které zasáhlo zejména bývalé trčkovské majetky (Hofman 2007). Zdejší kraj byl pak přímými vojenskými událostmi postižen v letech 1639 a 1640, kdy zde švédská a císařská vojska sváděla boj o Hradec Králové. Jednotky generála Banéra tehdy obsadily většinu okolních měst (Knapp 1887, 103). V dalších letech (1643-1645) pak švédská vojska opět nerušeně operovala v okolí Jaroměře a Smiřic (Knapp 1887, 105; Mertlíková-Č́ižek 2004, 104; Solař 1870, 133). Smiřický urbář zhotovený k roku 1655 pak uvádí, že ves Kusá Habřinka je zcela pustá, a že polnosti a louky jsou užívány žíželeveským dvorem a obyvateli Račic. Berní rula rovněž k roku 1654 uvádí, že Kusá Habřinka (4 selské grunty a 1 chalupník) je celá pustá, zapsána jsou však ještě jména majitelů jednotlivých gruntů (BR 14, 102). ${ }^{7}$ Rovněž při dělení smiřického dominia mezi syny Matyáše Gallase je Habřinka uvedena jako pustá a bez kalkulu (Doskočil 1953, 239).

Z výše uvedeného přehledu zápisů v urbářích a berní rule (tab. 1) vyplývá, že se ve vsi nenacházelo více než šest poddanských usedlostí (zápis 1619). V porovnání s ostatními vesnicemi smiřického panství co do počtu hospodářů i výměry polí se jednalo o jednu z menších vsí. Např́íklad

\footnotetext{
1 „(...) Malau Habřinku wes (...).“

2 Michal, Bartoš, Václav Čert, Vaněk Pekelský (přesán v pozdějším zápisu na Štěpána Němce) a Martin Havelků.

3 Digitalizované přepisy urbáŕů jsou k dispozici na: www.smirice.eu/usedlosti/smiricko1588_1730.pdf, cit. 25. 6. 2019.

4 Jan Mikulášků, Jan Brzek, Kryštof Němec a Vojtěch Havelka.

5 Petr Mikulášků, Adam Haběra, Tomáš Sirůček, Jiřík Havelka, Jan Knejslík a Jan Janásek.

6 Jan Mikulášků, Jan Šrám a Jan Vavruška.

7 Mikulášovský, Haběrovský, Širůčkovský, Havelkovský a Kneislíkovský grunt.
} 
Tab. 1. Přehled usedlých ve vsi Habřinka dle urbářů.

Tab. 1. Übersicht der Hintersassen im Dorf Habřinka laut Urbarien.

\begin{tabular}{|c|c|c|c|c|c|c|}
\hline $\begin{array}{l}\text { Pardubický } \\
\text { urbáŕ } 1521\end{array}$ & $\begin{array}{c}\text { Smiřrický } \\
\text { urbáŕ } 1588\end{array}$ & $\begin{array}{c}\text { Smiřický } \\
\text { urbáŕ } 1619\end{array}$ & $\begin{array}{c}\text { Smiřrický } \\
\text { urbář asi } 1642\end{array}$ & \multicolumn{2}{|c|}{$\begin{array}{c}\text { Berní rula } \\
1654\end{array}$} & $\begin{array}{l}\text { Smiřický } \\
\text { urbář } 1655\end{array}$ \\
\hline $\begin{array}{c}\text { Michal } \\
\text { Bartoš } \\
\text { Václav Čert } \\
\text { Martin } \\
\text { Havelků } \\
\text { Vaněk Pekel- } \\
\text { ský (přepsán } \\
\text { v pozdějším } \\
\text { zápisu na Ště- } \\
\text { pána Němce) }\end{array}$ & $\begin{array}{c}\text { Jan Mikulášků } \\
\text { Jan Brzek } \\
\text { Kryštof } \\
\text { Němec } \\
\text { Vojtěch } \\
\text { Havelka }\end{array}$ & $\begin{array}{c}\text { Petr } \\
\text { Mikulášků } \\
\text { Adam Haběra } \\
\text { Tomáš } \\
\text { Sirůček } \\
\text { Jiřík Havelka } \\
\text { Jan Knejslík } \\
\text { Jan Janásek }\end{array}$ & $\begin{array}{c}\text { Jan Mikulášků } \\
\text { Jan Šrám } \\
\text { Jan Vavruška }\end{array}$ & $\begin{array}{l}\text { Mikulášovský } \\
\text { Haběrovský } \\
\text { Širůčkovský } \\
\text { Havelkovský } \\
\text { Kneislíkovský }\end{array}$ & $\begin{array}{c}\text { Ves Kusá } \\
\text { Habřinka celá } \\
\text { pustá }\end{array}$ & Zcela pustá \\
\hline
\end{tabular}

sousední Lužany měly 9-11 usedlých (zápis 1588 a 1655), Hořiněves 20-25 (zápis 1634 a 1655), Žíželeves 21-24 usedlými (zápis 1634 a 1655) a Račice 22-29 usedlých (zápis 1588 a 1655). Dělením smiřického panství vzniklo nové panství Hořiněves, které připadlo Františkovi z Gallasu, který ho však již roku 1674 prodal hraběti Janovi ze Šporku (Sedláček 1883, 239). Po jeho smrti se sice tato část dostala do rukou mladšího syna Ferdinanda Leopolda ze Šporku, nicméně kvůli jeho povahovým rysům musela být správa majetku předána v letech 1702-1704 jeho staršímu bratrovi Františku Antonínovi ze Šporku (Sedláček 1882, 182; 1883, 239). V této době vzniká i na polnostech zaniklé vsi panský dvůr Frantov. Hořiněvské panství pak zůstává v rukou rodiny Šporků až do roku 1790, kdy ho odkupuje císařská dvorní komora z popudu císaře Josefa II. (Schaller 1790, 45).

\section{Lokalizace ZSV Habřinky a její umístění v krajině}

V současné době lze spolehlivě identifikovat polohu zaniklé středověké vsi ve středu pomyslného kruhu, který je tvořen vesnicemi Račice nad Trotinou, Habřina, Lužany, Žiželeves, Vrchovnice a Hořiněves (obr. 1). Pro tuto lokalizaci svědčí blízkost vsí Račic, Benátek a Máslojed, se kterými je Habřinka společně zmiňována v majetkových záznamech 15. století. Rovněž se jedná o území, jež spadalo pod smiřické a později hořiněvské panství. O změnách a restrukturalizaci v hranicích katastrálních území výše uvedených obcí v tomto území svědčí nepravidelné výběžky (zejména) račického a dále žiželeveského katastrálního území, které mohou nasvědčovat o rozdělení pozůstalých pozemků zaniklé Habřinky. Připomenout lze, že smiřický urbář z roku 1655 uvádí, že právě vesničané z Račic a Žíželevsi hospodaří na polích pusté vsi. Uprostřed území se rovněž nachází dvůr Frantov, který byl patrně založen, aby spravoval tyto zemědělské plochy. Konečně lze prostor zkoumané lokality ztotožnit se zaniklou vsí Habřinkou díky řadě toponym zachycených na mapách stabilního katastru a indikačních skicách. Jedná se např́ílad o názvy Zahabřinec mezi intravilánem vsi Račice a dvorem Frantov, dále o název Wpustegch u frantovského dvora, název Pustiny východně od Žíželevsi, nebo o název lesa (Wpustegch) v severní časti račického katastru. Na základě výše uvedených údajů tak lze spolehlivě vyvrátit domněnku některých badatelů (Doskočil 1953, 239; Roubík 1959, 103) umist'ující Habřinku do okolí vsi Chotěborky u Vilantic.

Místem založení Habřinky se stalo mírné ploché návrší, které se nachází mezi výše zmíněnými vesnicemi. Nejvyšším bodem je kóta $267 \mathrm{~m} \mathrm{n}$. m. situovaná západně od dvora Frantov. Na jihu zmíněné návrší plynule klesá k Frantovskému potoku, který se posléze vlévá do řeky Trotiny, která je zároveň nejvýraznější vodotečí v tomto prostoru. Podle starých map se bezejmenné vodoteče nacházely i severně od návrší a rovněž se slévaly do již zmíněné Trotiny. 


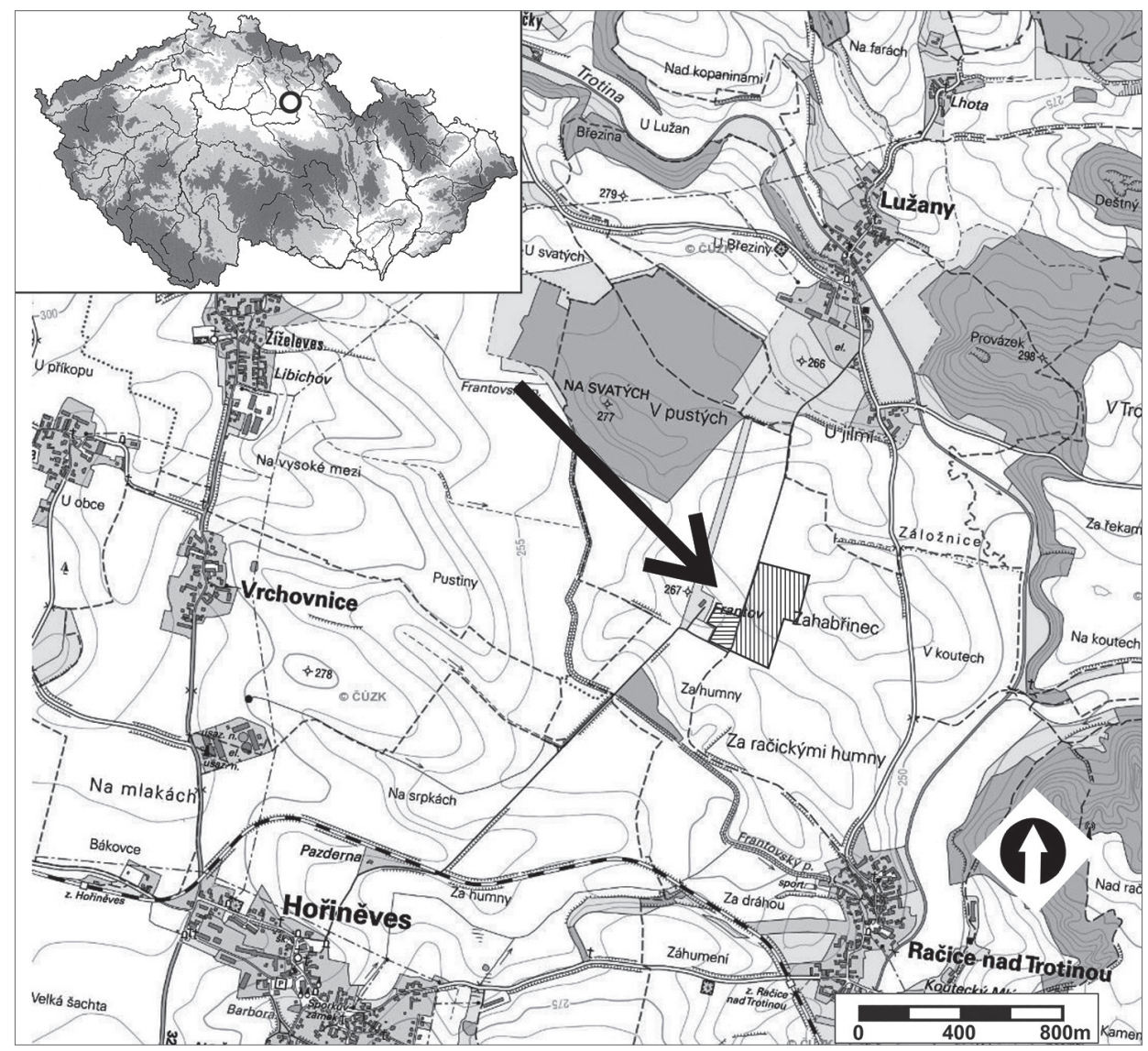

Obr. 1. Poloha stř̌edověké zaniklé vsi Habřinka, okr. Hradec Králové, a vyznačení zkoumaných areálů. Svislé šrafování geofyzikální prủzkum; vodorovné šrafování - povrchové prospekce.

Abb. 1. Lage der mittelalterlichen Dorfwüstung Habřinka, Bezirk Hradec Králové, und Kennzeichnung der untersuchten Areale. Schräg schraffiert - geophysikalische Untersuchung; waagerecht schraffiert - Oberflächenprospektion.

Na Müllerově mapě Čech je zkoumaná oblast znázorněna pouze schematicky, nicméně dvůr Frantov zde zakreslen je. Poněkud lépe je krajina zachycena na mapovém listu zachycujícím průběh válečných operací mezi Smiřicemi a Jaroměří v letních měsících roku $1758 .{ }^{8}$ Zde je frantovský dvůr zakreslen jako čtyřboký, vojenský kartograf zaznamenal i zmíněné návrší a systém cest mezi Hořiněvsí, Račicemi a Habřinou.

Důležité svědectví přináší listy č. 78, 79, 95 a 96 prvního vojenského (josefského) mapování, jehož rektifikace proběhla na počátku 80 . let 18. století (obr. 2). Podstatné je zaměřit se na průběh cest ve srovnání se stavem na druhém (mladším) vojenském mapování. Na starším mapování vedou do míst dvora Frantov dvě hlavní cesty: od západu ze Žíželevsi a od jihu z centra panství z Hořiněvsi. Tyto dvě cesty se kř́žźi východně od dvora, jedna pokračuje severním směrem dál k Jeřičkám a druhá stoupá ke Frantovu, odkud směřuje severovýchodním směrem k samotě U Jílmí, která se nachází jižně od Lužan a odkud vede cesta do vsi Habřiny. Na druhém vojenském

8 FeldtLaager der Kayserlich-Königlichen unter Hochen Commando des Herren General FeldMarchallen Graffen von Daun. Uloženo v Österreichische Nationalbibliothek ve Vídni, sign. FKB V.57,58,06,44 KAR MAG. Dostupné online, cit. 25. 4. 2019. 


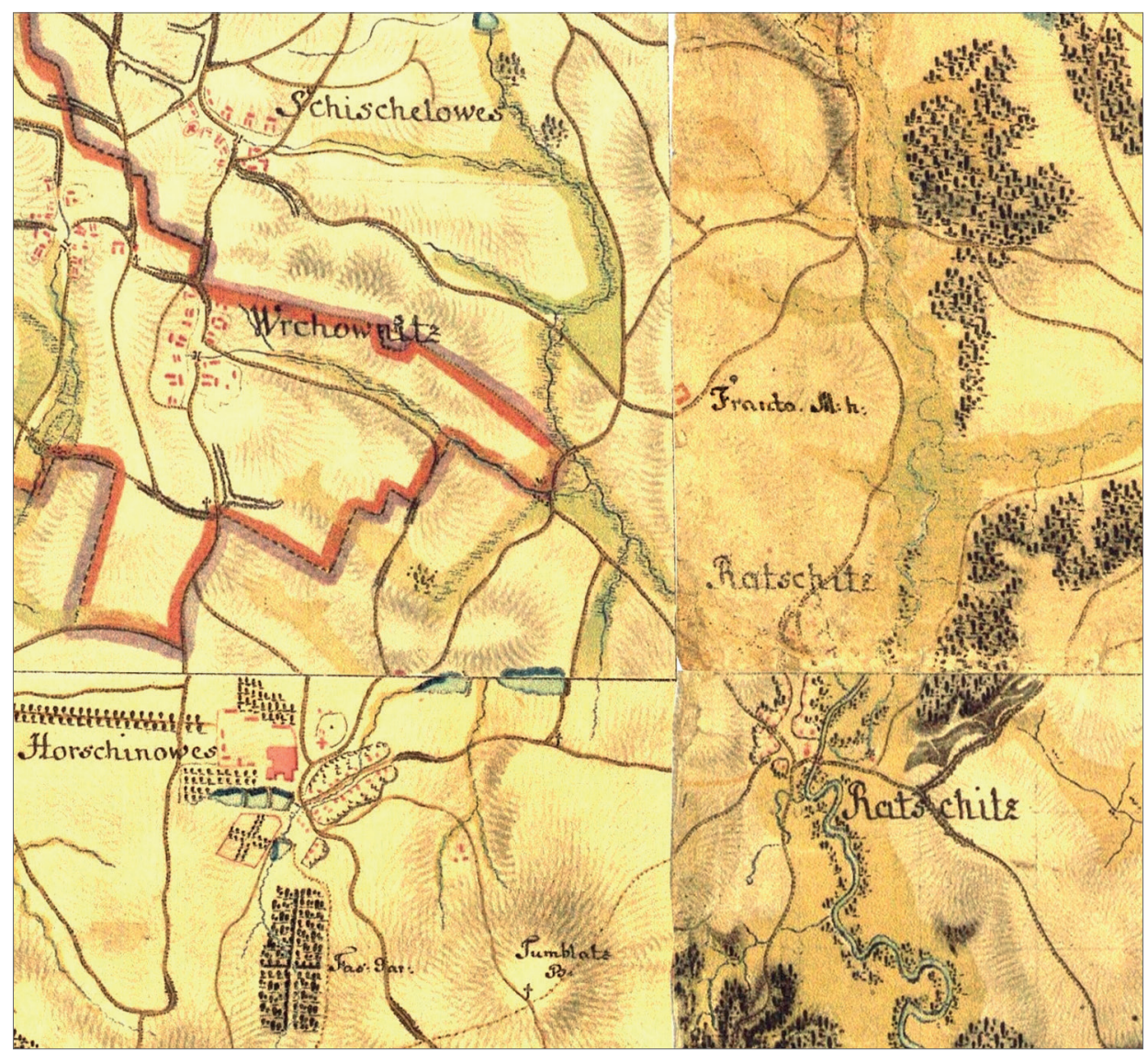

Obr. 2. Prostor bližšího okolí zaniklé vsi Habřinka na mapových listech 1. vojenského mapování. Dvůr Frantov umístěn ve středu obrázku. Spojené mapové listy č. C78, C79, C95, C96. Zdroj http://oldmaps.geolab.cz/.

Abb. 2. Raum der näheren Umgebung der mittelalterlichen Dorfwüstung Habřinka auf Kartenblättern der 1. militärischen Kartierung. Frantov-Hof in der Bildmitte. Verbundene Kartenblätter Nr. C78, C79, C95, C96. Quelle http://oldmaps.geolab.cz/.

mapování se situace změnila ve vedení cesty od Hořiněvsi přes Frantov a dále severním směrem. Zejména se jedná o napřímení trasy do rovných úseků. Úsek mezi Hořiněvsí a Frantovem je lemován stromořadím. Změna ve vedení pak nastává v úseku severně od dvora Frantov, kdy cesta již nevede na samotu U Jílmí, ale př́ímo severně k Lužanům. Vzhledem k tomu, že kartograf prvního vojenského mapování v nejbližším okolí běžně zaznamenával přímé (rovné) vedení cest, ${ }^{9}$ nelze se domnívat, že nerovné vedení cesty (Hořiněves-Frantov - U Jílmí) na josefském mapování je pouze způsobeno nepřesným zakreslením. Na katastrálních mapách poloviny 19. století (z roku 1840) je situace totožná s druhým vojenským mapováním. Doplnit lze, že parcely v tratích Zahabřinec a U Gylem mají kolmou orientaci na předpokládané vedení cesty zaznamenané na prvním vojenském mapování, zatímco s mladší rovnou cestou Frantov-Lužany nekorespondují.

Lze tak shrnout, že původní cesta probíhající přes prostor zaniklé vsi Habřinka (a pozdějšího dvora Frantov) vedla od Hořiněvsi a Žíželevsi severovýchodním směrem dále ke křižovatce

9 Např́iklad blízká císařská silnice Hradec-Hořice, cesta mezi Hořiněvsí a Benátkami, Dohalicemi a Sadovou, Trotinou a Smiřicemi, Rodovem a Smiřicemi atd. 
u samoty U Jílmí a směřovala k Habřině. Tedy nikoliv - jako je tomu dnes (poprvé zachyceno na druhém vojenském mapování) - přímým severním směrem do Lužan. K tomuto zjištění se ještě vrátíme při interpretaci geofyzikálního měření a povrchových sběrů.

\section{Nedestruktivní prospekce}

Cílem nedestruktivních prospekčních metod bylo ověřit předpokládanou lokalizaci zaniklé vsi, její rozsah, topografii a popřípadě díky zisku archeologických nálezů upřesnit počátky založení lokality.

\subsection{Povrchové sběry}

První fáze povrchových sběrů proběhla během roku 2004 a později byla stručně publikována (Drnovský 2005). Pozornost tehdy byla věnována prostoru východně od dvora Frantov. Sběr byl proveden na ploše $120 \times 130$ m ve čtvercové síti o rozměrech $10 \times 10 \mathrm{~m}$. Západní okraj zkoumané plochy byl ohraničen již zmíněným dvorem Frantov, jižní a východní pak polními cestami a severní okraj postupně vyznívajícím počtem nálezů (kromě recentní složky). Při této prospekci se podařilo na základě výrazné koncentrace vrcholně středověké keramiky potvrdit lokalizaci zaniklé vsi (Drnovský 2005, 245). Další sběry na lokalitě proběhly v letech 2017 a 2018. Jejich cílem bylo ověřit koncentraci výskytu nálezů a získat reprezentativnější vzorek keramických fragmentů k datování souboru. Prospekce byla opět provedena ve čtvercové síti, jejíž umístění odpovídalo dřívějším sběrům. Vzhledem $\mathrm{k}$ tomu, že morfologie terénů v místech povrchových prospekcí není členitá, nemusíme brát v potaz možný transport artefaktů vlivem eroze a dalších postpozičních procesů. $V$ rámci vyhodnocení výskytu nálezů v rámci zkoumané plochy uvažujeme o př́tomnosti koncentrací keramiky v místech zaniklého osídlení (primární vazba mezi nálezy a osídlením). Samotná problematika distribuce sídlištního odpadu na středověkých lokalitách je dlouhodobě řešena (např. Kuna 2004, 317-323 - zde odkazy na další literaturu). Do analýzy nebyly zahrnuty artefakty výrazně mladší, nežli je předpokládaný zánik vsi. Nebyla proto vyhodnocena recentní keramika 19. a 20. století, jež se vyskytovala průběžně ve většině čtverců. Touto selekcí tak mohly být zčásti vyřazeny nálezy se sekundární vazbou na osídlení (přemístěné v důsledku rozorání cest, vyvezením z jiných poloh v souvislosti s hnojením apod.).

Během série sběrů byla opakovaně prokázána koncentrace nálezů kumulující se $\mathrm{v}$ oválu o velikosti ca $40 \times 60 \mathrm{~m}$. Výše uvedené soustředění artefaktů se oproti zbytku zkoumané plochy zřetelně odlišuje počtem prŕtomných jedinců. Díky tomu lze jeho hranice poměrně dobře vymezit.

Během série sběrů byla opakovaně prokázána koncentrace nálezů kumulující se v oválu, který lze vymezit krajními čtverci H6, H10, C7 a C10. Výše uvedené soustředění artefaktů se oproti zbytku zkoumané plochy zřetelně odlišuje počtem přítomných jedinců. Díky tomu lze jeho hranice poměrně dobře vymezit (tab. 2; obr. 6).

Celkem se podařilo získat téměř 1400 keramických jedinců, z nichž většina náleží kuchyňské a stolní keramice. Pouze čtrnáct fragmentů jsme schopni určit jako zlomky pocházející z kamnářské keramiky (4 menší zlomky ČVS, 10 zlomků komor). Vzhledem k charakteru souboru nepřekvapí, že se jedná o kolekci, pro kterou je charakteristická značná fragmentárnost (87 \% jedinců je možno umístit do kružnice o průměru $2 \mathrm{~cm}$ ). Keramický soubor byl podroben deskripci za účelem poznání základní morfologie, technologie a výzdoby, s cílem stanovit relativní chronologii osídlení lokality. Vzhledem k nestratifikovanosti a fragmentárnosti souboru považujeme za neúčelné tř́ídit keramiku podle keramických tříd (Vařeka 1998, 124). V souboru je možno definovat čtyři vůdčí keramické technologické skupiny, ${ }_{10}^{10}$ jejichž zástupci dohromady tvoří 95,6 \% nálezů. Ve zbylých 4,4 \% souboru se jedná o keramické fragmenty, které nelze přiřadit k žádné z hlavních keramických skupin, a zároveň postrádají pro svou ojedinělost možnost vyhodnocení.

10 Definice pojmu a vymezení keramických technologických skupin např. Peroutková-Matějková 2008; Matějková 2014; Doležalová 2015 , 54. 
Výjimku tvoří dva fragmenty, jež lze přiřadit k okruhu loštické polokameninové produkce. Jedná se však o atypické fragmenty z těl nádob, takže nelze blíže určit jejich tvar. Jejich šiřka napovídá, že se spíše jednalo o stolní zboží (poháry). Vzhledem k nízkému počtu a charakteru původu celého souboru však nelze s jistotou nálezy spojit přímo se vsí Habřinkou, nebot' nelze vyloučit transport na místo nálezu jinou cestou.

Nejhojněji zastoupenou keramickou skupinu tvoří technologická skupina $C$, která tvoří $43 \%$ souboru. Jedná se oxidačně pálenou hrnčinu dosahující oranžových odstínů. Pokud lze určit typ zakončení nádob, převládají hrncovité okraje. Nečetná výzdoba je omezena na jednoduché oběžné ryté linie, ojediněle pak rádélko. Okraje tohoto zboží jsou utvářeny jako ovalené a oble i ostře přehnuté a zavinuté (vše bez vnitřního prožlabení). Nálezy této skupiny bychom mohli přiřadit $\mathrm{k}$ nejrozšířenějšímu druhu zboží vrcholného a pozdního středověku v severovýchodních Čechách, která se vyskytuje prakticky na všech současných lokalitách (Drnovský 2018, 77). Počátky výskytu této keramiky lze sledovat od první poloviny 15. století (Matějková 2014, 100), a na dlouhé období produkce ukazuje její přítomnost ve stratifikovaných situacích jímek z Pražského hradu ještě během poloviny 16. století (Blažková 2011, 392-436). Ostatně jako ekvivalent k polévanému zboží tato hrčina přežívala ještě v pokročilém raně novověkém období.

Druhou nejčastěji zastoupenou keramickou skupinu představuje technologická skupina $D$, jež tvoří 24,7 \% všech nálezů. Jedná se o hrnčinu pálenou za př́stupu vzduchu, která je opatřena vnitřní glazurou různých barevných odstínů. Výzdoba se téměř neuplatňuje, výjimečně se objevuje rádélko a jednoduché horizontální line. Keramické těsto je jemnozrnné s př́iměsí jemného písčitého ostřiva $(0,1-0,3 \mathrm{~mm})$. Většina zlomků pochází z těl nádob, které jsou tenkostěnné (vyjma mís a pánví). Rozpoznat lze kromě nejčastějších hrnců i okraje mís, talírư a pánví, ke kterým patří i fragmenty neglazovaných nožek. Nástup a výraznější uplatnění glazovaného zboží lze ve východních Čechách, obdobně jako v jiných regionech, klást až od závěru 15. století, předtím se výrazně uplatňuje spíše na trojnohých pánvích (Matějková 2014, 104; Drnovský 2018, 80).

Zbylé dvě keramické skupiny se v souboru vyskytují již v menším zastoupení. Keramická technologická skupina $A$ tvoří 14,4 \% a keramická technologická skupina B pak 13,5\%.

Pro prvně uvedenou skupinu A je charakteristické hrubší zpracování, což je způsobeno zejména vlastnostmi užitého materiálu. Povrch je krupičkový a vystupují na něm zrnka hornin a písku $(0,4-1,5 \mathrm{~mm})$, která jsou obsažena i ve struktuře keramické hmoty. Barva keramiky se pohybuje $\mathrm{v}$ odstínech hnědobéžové až hnědošedé barvy. Hrčina byla rovněž pálena za prrístupu vzduchu, ale podle vzhledu některých jedinců je zřejmé, že proces nebyl zcela homogenní. V souboru lze rozpoznat pouze hrncovité tvary a $\mathrm{v}$ jednom př́padě i knoflík poklice (obr. 3:8). Okraje se vyskytují ve formě tzv. nepravých okruží, tedy vzhůru vytažených okrajů s vnitřním prožlabením, a to v nízké i vysoké formě (obr. 3:1-7, 9-10). Výzdoba je tvořena oběžnou (místy nepravidelnou) šroubovicí, rytou jednostopým rydlem (rozestupy rýh kolísají). Šiřka samotných rýh se pohybuje od 1,3 mm až po 3,5 $\mathrm{mm}$ (obr. 3:11-22).

Analogickou hrnčinu lze nalézt na řadě blízkých lokalit, kromě již zmíněných sídel Vražba a Rotemberk lze uvést například dvě zaniklé sídelní polohy u vesnice Habřiny 

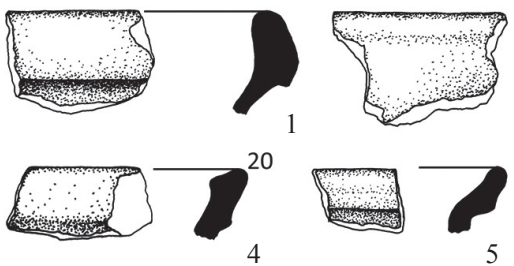

5
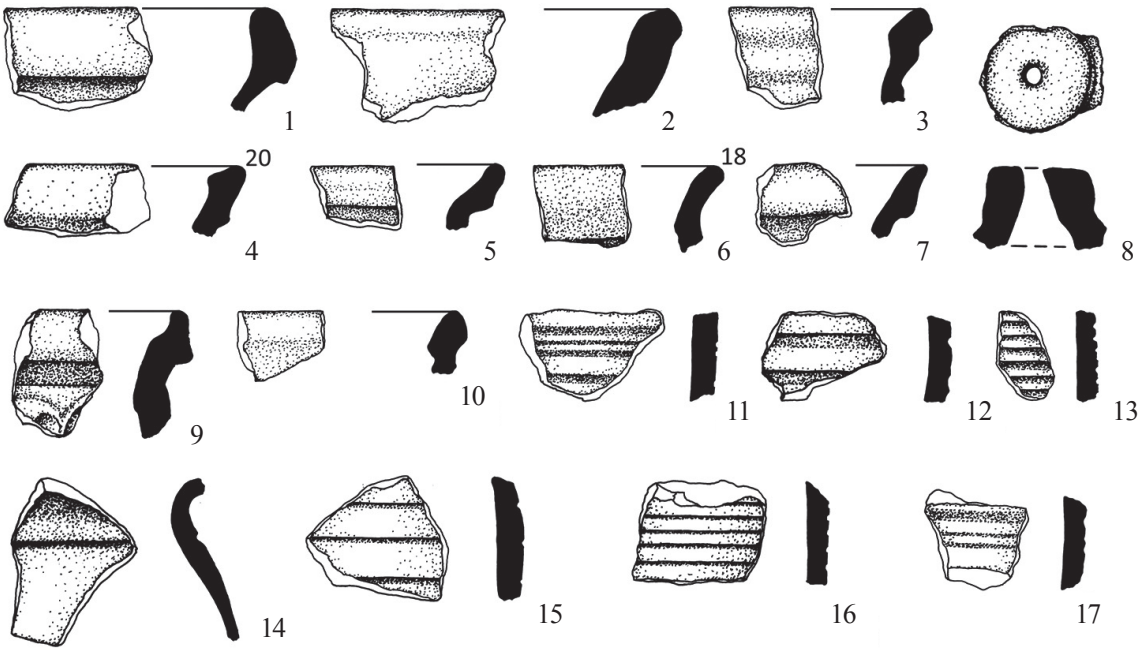

14
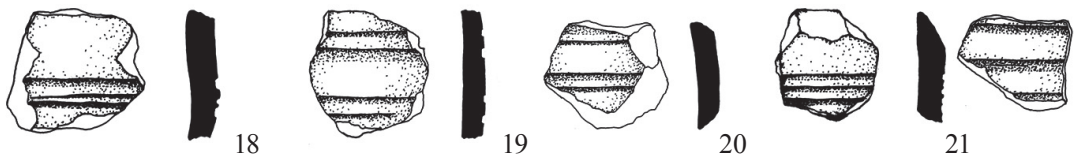

21
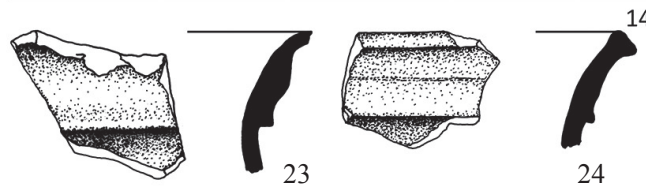

24
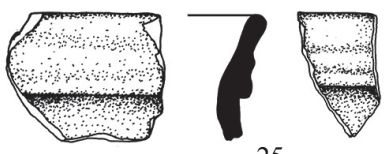

25

26
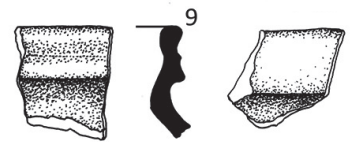

27
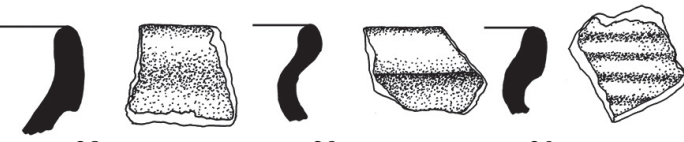

30

31

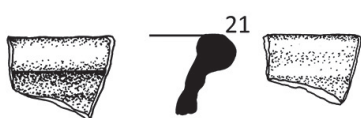

32

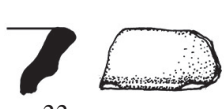

33
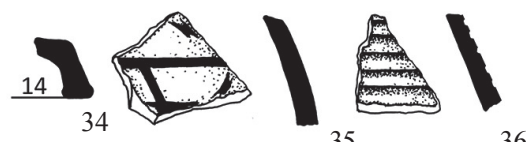

35

36

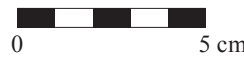

Obr. 3. Keramické nálezy. 1-22 keramická skupina A; 23-36 keramická skupina B.

Abb. 3. Keramikfunde. 1-22 Keramikgruppe A; 23-36 Keramikgruppe B.

(Bláha-Kalferst-Sigl 2004, 20; 2005, 5) či zaniklého sídliště u vsi Neznášova (Kalferst-SiglVokolek 1991-1992, 19). Nálezy z výše uvedených poloh určil M. Ježek do období druhé poloviny 13. století až průběhu 14. století (2007, 559-569). Do stejného období pak patří i shodná keramika z rozsáhlých zaniklých sídlišt' západně od vsi Benátky (Bláha-Kalferst-Sigl 2004, 5; Drnovský 2013, 50; Kalferst-Sigl-Vokolek 1989, 3; Kalferst-Sigl 1985, 6; Sigl-Vokolek 1986, 6; 
Vích-Vokolek 1997, 3). Analogická keramika pochází i z poloh v okolí jaroměřské sídlištní aglomerace, které jsou rovněž datovány do průběhu 13.-14. století, na katastrech Dolan, Dolních a Horních Dolců a i intravilánu Jaroměře (Bláha 1998, 50-72; 2000, 89-91). Pochopitelně lze nalézt obdobnou keramiku rovněž v různých stratifikovaných situacích na území královéhradecké městské aglomerace (Bláha-Sigl 2014; Richter-Vokolek 1995, 57-69). Obecně bývá tato skupina keramiky označována jako zboži hradištní tradice apod., jedná se však o nepřesný termín, který v různých regionech může představovat odlišnou keramiku, zároveň toto označení odkazuje k předchozímu hradištnímu období, ačkoliv na řadě lokalit (i výše uvedených, zejména pak v Hradci Králové) nálezy keramiky tvarovou náplní i výzdobou odpovídají již vrcholně středověké produkci (srov. Drnovský 2018, 76; Matějková 2014, 96; Wolf 2005, 94-95).

Pro poslední zastoupenou keramickou skupinu B je charakteristický oxidační výpal a světle béžové či světle šedobéžové zabarvení. Okraje hrnců jsou formovány jako tzv. nepravá okruží, tedy vzhůru vytažené okraje s vnitřním prožlabením, ale i jako klasická okruží. V menším počtu se objevují ovalené okraje s vnitřním prožlabením (obr. 3:23-30). V několika případech je přítomen i džbán (vysoké okruží, výlevka). Výzdoba této hrčiny je tvořena vývalkovou šroubovicí, popřípadě červeným malováním, v podobě jednoduchých linií a jejich kombinací (obr. 3:35-36).

Ačkoliv je posuzovaná kolekce fragmentární, lze díky analogiím z blízkých lokalit, odkud pochází ucelenější soubory, uvedenou hrnčinu spojit s keramikou označovanou nejčastěji jako červeně malovaná keramika, či jako světlá keramika. Makroskopicky identická keramika se nachází na blízkých opevněných sídlech Vražba (Sigl 1979) a Rotemberk (Kalferst 1993), stejně jako v archeologických situacích nedaleké královéhradecké městské aglomerace (Richter-Vokolek 1995, 69-72). Zastoupena je i na řadě dalších vzdálenějších lokalit (Drnovský 2018, 77). Obecně je její výskyt spatřován ve stabilizaci městského prostředí se specializovanou městskou výrobou (Klápště 1998, 156). Její produkce bývá kladena do období od druhé poloviny 13. století až po celé 14. století, př̌ičemž vyznívat může ještě na počátku 15. století (Drnovský 2018, 79; Havrda-Matějková 2014, 38-41; Matějková 2014, 98-100; Wolf 2004, 235-236).

Jestliže bychom měli shrnout výsledky zpracování keramického souboru, tak lze z hlediska chronologie vyčlenit tři základní horizonty: 1) keramika staršího vrcholně středověkého období, 2) keramika vrcholně středověká, 3) pozdně středověká keramika a raně novověké zboží. Není překvapením, že nejvíce artefaktů lze přiřadit nejmladšímu chronologickému horizontu, který je tvořen zástupci skupiny $\mathrm{D}$, a zčásti i jednici keramické skupiny C. Samotná skupina C zaujímá jak vrcholně středověké, tak i mladší období. Vymezit hranici mezi starší a mladší vrcholně středověkou keramikou je nesnadné. Problematiku absolutního datování keramických souborů staršího období shrnul pro tento region naposledy M. Ježek (2007, 527-530), pro mladší středověkou keramiku pak sumarizovali základní aspekty naposledy P. Drnovský $(2018,78-80)$ a J. Skala s R. Bláhou (2018, 1008-1011). V našem souboru se jako důležitý znesnadňující faktor přidává zejména fragmentárnost keramiky pocházející z povrchových sběrů a absence stratigrafických vazeb. Analogické soubory obsahující nálezy keramické skupiny A bývají na různých lokalitách severovýchodních Čech chronologicky řazeny od druhé poloviny 13. století a s výskytem až do poloviny následujícího století, během kterého se však postupně vytrácí (Drnovský 2018, 78-79). V prŕípadě tohoto zboží je nutné sledovat a posuzovat zejména formu výzdoby a tvarování okrajů. Druhá keramická skupina B má své počátky v širším zkoumaném regionu během poslední třetiny 13. století. Její produkce jistě trvá po celé 14. století a může se objevit na počátku 15. století, kdy se již postupně začíná uplatňovat produkce oxidační hrnčiny oranžových odstínů, kterou jsme na lokalitě schopni ztotožnit se skupinou C (Drnovský 2018, 79; Matějková 2014, 98-100; Wolf 2004, 235-236). Vzhledem k charakteru zástupců keramických skupin A a B na zkoumané lokalitě bychom měli být opatrní s přímočarým zařazením do průběhu druhé poloviny 13 . století. V porovnání s jedinou lépe poznanou stratigrafickou situací na královéhradeckém návrší (Richter-Vokolek 1995, 57-69) a s přihlédnutím ke skutečnosti, že se nacházíme ve venkovském prostředí, se přikláníme spíše k pozdější dataci. Určitě však lze předpokládat vysazení a počátek existence vsi Habřinky nejpozději na přelomu 13. a 14. století. 


\subsection{Geofyzikální měření}

Vesnice $\mathrm{z}$ vrcholně středověkého až časně novověkého období nepatří v českém prostředí $\mathrm{k}$ často geofyzikálně zkoumaným lokalitám. I když se v literatuře můžeme setkat s výsledky několika takovýchto měření, jednalo se $\mathrm{v}$ těchto př́ípadech především o průzkumy menšího rozsahu, zaměřené na detekci a identifikaci jednotlivých objektů nebo nálezových situací. K takovým patří například průzkum v areálech zaniklých středověkých vsí Vyžlovka, okr. Kolín (Křivánek 2004, 166, obr. 4:29), a Kří, k. ú. Kersko, okr. Nymburk (Klír 2008, 198, plán 7-10; Křivánek 2008, 73, 74, obr. 4). Na území Moravy se stav bádání výrazně posunul v posledních letech, kdy zde bylo provedeno několik velkoplošných geofyzikálních měření. Řadí se sem např́íklad průzkumy středověkých vsí Opatovice (Dresler a kol. 2015) a Vojšice (Dresler a kol. 2019). V prostoru severovýchodních Čech výzkum středověkých vesnic pomocí geofyzikálního měření dosud zcela absentoval. Průzkum vsi Habřinka je tak prvním svého druhu. Zároveň, i když nepokryl celou plochu zaniklé vsi, jej můžeme v českých podmínkách označit za jeden z prvních průzkumů, který zaznamenal podstatnou část osídleného areálu, přičemž umožnil vyjádřit se k rozsahu a struktuře zaniklé vsi.

Geofyzikální průzkum v předpokládané poloze zaniklé vsi Habřinka se uskutečnil v říjnu 2018. Jako nejvhodnější metoda pro průzkum tohoto typu lokality byla zvolena magnetometrie. Ta dokáže $\mathrm{v}$ př́ṕpadě jakýchkoliv sídlištních lokalit zprostředkovat $\mathrm{v}$ krátkém časovém horizontu základní informace o rozsahu a tvaru, jakož i o členění a vnitřní struktuře zástavby ve zkoumané poloze. Při magnetické prospekci je měřena intenzita magnetického pole Země, v němž jsou registrovány anomálie poukazující na př́itomnost podpovrchových struktur rozličného charakteru. Základem pro rozpoznání archeologických objektů je jejich rozlišitelnost vůči okolnímu prostředí. Nejdůležitější roli přitom nehrají absolutně magnetické hodnoty výplní těchto objektů, ale spíše kontrast mezi zásypem objektu a okolním

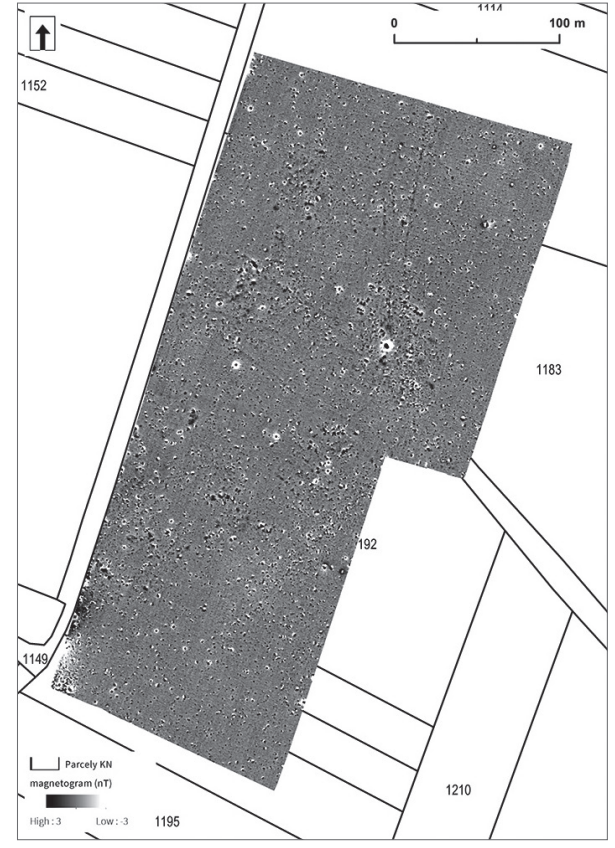

Obr. 4. Zaniklá vesnice Habřinka. Magnetogram. Abb. 4. Dorfwüstung Habřinka. Magnetogramm. prostředím. Pro intenzitu a tvar magnetické anomálie, a s tím spojený výsledek měření, je určujících několik faktorů, především jsou to ale složení, zachovalost, velikost, tvar a hloubka zkoumaného objektu. Na místech se zaniklým vrcholněstředověkým osídlením můžeme pozitivní výsledky očekávat při lokalizaci struktur, jejichž magnetizace se vytvořila působením geomagnetického pole v podmínkách značných teplotních změn. Patří sem např́iklad pece a přepálené vrstvy, ale také železné předměty různého charakteru. Dobře detekovatelné jsou i zahloubené objekty sekundárně vyplněné tmavšími hlínami s organickými zbytky a magnetickými minerály. Můžeme sem zařadit různé sídlištní jámy, žlaby, příkopy a v ideálních prrípadech i zaniklé cesty.

Prvotním cílem geofyzikální prospekce u Hořiněvsi bylo ověření předpokladu, že se zde nacházela zaniklá ves Habřinka. Analýza písemných pramenů, historických mapových podkladů, a především povrchových sběrů tomu napovídala, nicméně za jednoznačný doklad můžeme považovat až potvrzení 
prrítomnosti podpovrchových archeologických objektů v tomto prostoru. Druhým cílem bylo zjistit bližší informace o původním vzhledu vesnice, především její velkosti, formě a případně i vnitřním členění, na které poukazovaly zachované písemné prameny.

Vzhledem k rovnému terénu bez vyšší vegetace bylo možné využít fluxgate magnetometr LEA MAX se sondami FEREX CON 650, který je vhodný pro velkoplošný archeogeofyzikální průzkum. Přístroj je konstruován jako gradiometr pro měření vertikálního gradientu lokálního magnetického pole a je schopen zaznamenávat hodnoty intenzity magnetického pole s přsností $0,1 \mathrm{nT} / \mathrm{m}$. Horizontální vzdálenost mezi deseti sondami, jimiž př́istroj disponuje, byla $0,5 \mathrm{~m}$. Vertikální vzdálenost mezi dvěma senzory v každé sondě je 0,65 m. Plochy byly geofyzikálně prozkoumány prŕímo za použití RTK GNSS (Real Time Kinematic Global Navigation Satellite Systems). Magnetometr byl použit v ATV módu.

Celkově měla plocha prozkoumaná magnetometrem rozlohu 7,3 ha (obr. 1, 4). Průzkum se soustředil na mírné návrší, východně od dvora Frantov. Zajímavé výsledky lze očekávat v budoucnu i při geofyzikálním průzkumu plochy, kde proběhly pouze povrchové sběry, tento terén byl totiž v čase prospekcí nedostupný.

\section{Interpretace}

V současné době lze spolehlivě lokalizovat zaniklou vesnici Habřinku, kterou v písemných pramenech registrujeme od průběhu 15. až do první poloviny 17. století. Díky prostorové distribuci keramiky a magnetometrickému měření jsme schopni vymezit areál zaniklé vsi. Tvar intravilánu by mohl odpovídat tvarům vsí s dvoustrannou návsí, či alternativně komunikačním návesním vsím dle typologie J. Pešty (2000).

Magnetická prospekce polohy odhalila četné anomálie, které můžeme interpretovat jako archeologicky relevantní objekty či struktury (obr. 4, 5, 6). Celkově jsme digitalizovali více než 400 takových anomálií, jejich skutečný počet je však ještě větší. Jedná se o magneticky pozitivní anomálie, které se dají interpretovat jako sídlištní jámy různého tvaru a funkce. Při větších strukturách můžeme uvažovat o pozůstatcích domů. Většina zjištěných struktur má kulatý nebo oválný tvar. Některé jsou nepravidelné. Nenacházíme zde žádné struktury, které bychom mohli jednoznačně označit za typické objekty středověké vesnice, jako jsou domy, kůlny, studny nebo ohrady. U některých z detekovaných anomálií se dokonce nemusí jednat o archeologické objekty. Malé pozitivní anomálie jsou totiž rozptýlené téměř po celé ploše průzkumu a mohou být za nimi i struktury pedologického původu.

Navzdory nejistému výsledku magnetického průzkumu, kdy se jednotlivé anomálie neprojevují jako typické archeologické objekty, můžeme na výsledných mapách sledovat tendenci k vytváření samostatných skupin objektů. Pro tyto je typická přítomnost většího počtu objektů, struktur větších rozměrů, ale hlavně magneticky pozitivního šumu v pozadí, který interpretujeme jako rozorané archeologické objekty a vrstvy. Poukazují na místa s intenzivnějšími sídelními a hospodářskými aktivitami ve středověku a můžeme sem lokalizovat jednotlivé hospodářské usedlosti. Celkově je na magnetogramu viditelných šest až sedm takových struktur. Nejvýrazněji se projevují čtyři nacházející se v severní a centrální části plochy. Nejmenší areál zabírá plochu pouze ca $500 \mathrm{~m}^{2}$. Největší areál má $3700 \mathrm{~m}^{2}$. Zbývající mají poměrně podobné rozměry s plochou $1600 \mathrm{~m}^{2}$ až $2600 \mathrm{~m}^{2}$. Potenciální hospodářské usedlosti tvoří dvě řady, probíhající ve směru severovýchod-jihozápad. Na základě absence dalších takových struktur v severní části magnetogramu můžeme předpokládat, že dále tímto směrem se výraznější osídlení nenachází. Další podobné struktury by se daly předpokládat západně od plochy průzkumu. Minimálně jeden hospodářský dvůr zde můžeme očekávat na základě rozptylu keramického materiálu získaného pomocí povrchových sběrů. Plocha s největší koncentrací archeologických artefaktů dosahuje ca $2500 \mathrm{~m}^{2}$, což plně odpovídá rozsahu jednotlivých usedlostí detekovaných geofyzikálním průzkumem. Poloha usedlosti lokalizované povrchovými sběry navíc plně koreluje se zjištěními z geofyzikálního průzkumu. Daná usedlost se nachází v linii se západní řadou usedlostí 


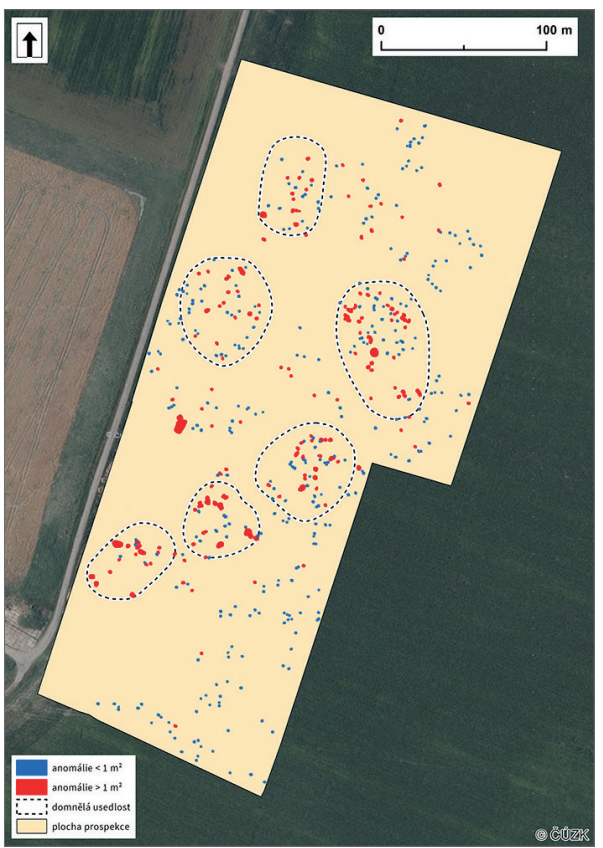

Obr. 5. Zaniklá vesnice Habřinka. Interpretace geofyzikálního průzkumu.

Abb. 5. Dorfwüstung Habřinka. Interpretation der geophysikalischen Untersuchung.

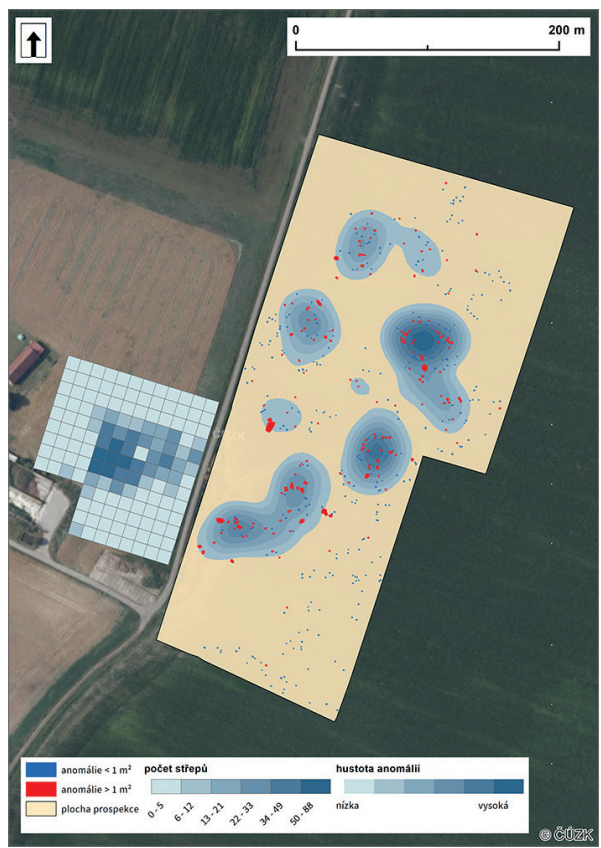

Obr. 6. Zaniklá vesnice Habřinka. Hustota geofyzikálně detekovaných archeologických objektů a sběrového materiálu.

Abb. 6. Dorfwüstung Habřinka. Dichte der geophysikalisch detektierten archäologischen Objekte und des gesammelten Materials.

a teoreticky mohla tvořit její jižní okraj. V celém zkoumaném prostoru tak můžeme sledovat sedm až osm shluků objektů / sběrových artefaktů, které nám zde umožňují předpokládat stejný počet usedlostí. Komunikace, kterou předpokládáme $\mathrm{v}$ prostoru mezi dvěma řadami hospodářských usedlostí, v geofyzikálních datech žádné stopy nezanechala. Ze struktur pozorovaných na otisku císařského katastru a ortofotografiích ale můžeme na magnetogramu sledovat průběh cesty probíhající ve směru sever-jih v severovýchodní části plochy a několik dalších lineárních struktur, které však souvisí s polním systémem v novověku (obr. 4, 5, 6).

Zjištěná lokalizace, rozsah a tvar vesnice koreluje s kartografickými prameny a podobou parcel zachycených na mapách stabilního katastru (obr. 7). To, že zástavba vsi byla osově orientována ve směru JJZ-SSV, se shoduje s vedením cesty zaznamenané na prvním vojenském mapování, která od dvora Frantov vedla tímto směrem k samotě U Jílmí. Teprve později byly cesty mezi Hořiněvsí, Frantovem a Lužany upraveny do přímého vedení a od Frantova pak téměř přesným severním směrem do Lužan, tato situace je prvně zachycená na druhém vojenském mapování. Na císařském otisku stabilního katastru z roku 1840 je rovněž zachyceno nové vedení cesty Frantov-Lužany. V uspořádání polností a parcelace je možno spatřovat proběhlou transformaci. V kontrastu proti sobě stojí scelené dominikální pozemky náležející k frantovskému dvoru s parcelami východně od dvora. Tyto parcely, které jsou součástí račické plužiny, jsou kolmé na předpokládané vedení starší cesty a korespondují s uvažovaným půdorysem zaniklé Habřinky.

V písemných pramenech je uváděno, že polnosti zaniklé vesnice jsou obhospodařovány žíželeveským dvorem a obyvateli Račic. Patrně v době správy Františka Antonína Šporka byl zrrízen dvůr Frantov. Ten byl tak založen v prostoru západně od zaniklé vsi na nejvyšším 
místě mírného návrší. Zatímco východní část plužiny zaniklé vsi zůstala zachována a přičleněna $\mathrm{k}$ polnostem sousedních Račic nad Trotinou, samotný prostor vsi a západní část plužiny byly sceleny a přičleněny $\mathrm{k}$ Frantovu. Za povšimnutí stojí nepravidelná louka (naise wiesen), která je umístěna zhruba doprostřed parcely č. 841. Střed tohoto prostoru vykazuje stopy zvýšené vlhkosti dodnes a při srážkově nadprůměrných obdobích či po jarním tání se zde déle drží vlhkost. Teoreticky by se mohlo jednat o místo, kde se i v době provozu vsi vyskytovala prŕležitostná nádrž vody. Vzhledem k tomu, že magnetometrické měření nezachytilo konstrukci hráze, nebo doklad stálejší vodní plochy, zůstává tento předpoklad $\mathrm{v}$ rovině úvah.

Otázkou též zůstává, jak vlastně vypadala zástavba a celková podoba vsi. Na první pohled je zřejmé, že měřením se nepodařilo identifikovat zřetelně definovaný půdorys vrcholně středověké vsi, ve kterém by šlo pozorovat vymezené hranice jednotlivých usedlostí a staveb, které známe z řady středoevropských lokalit dochovaných bud' v podobě terénních reliktů, či podrobené geofyzikálnímu měření. Do problematiky vstupuje i skutečnost, že z prostředí širšího Královéhradecka, respektive severovýchodních Čech dosud neznáme

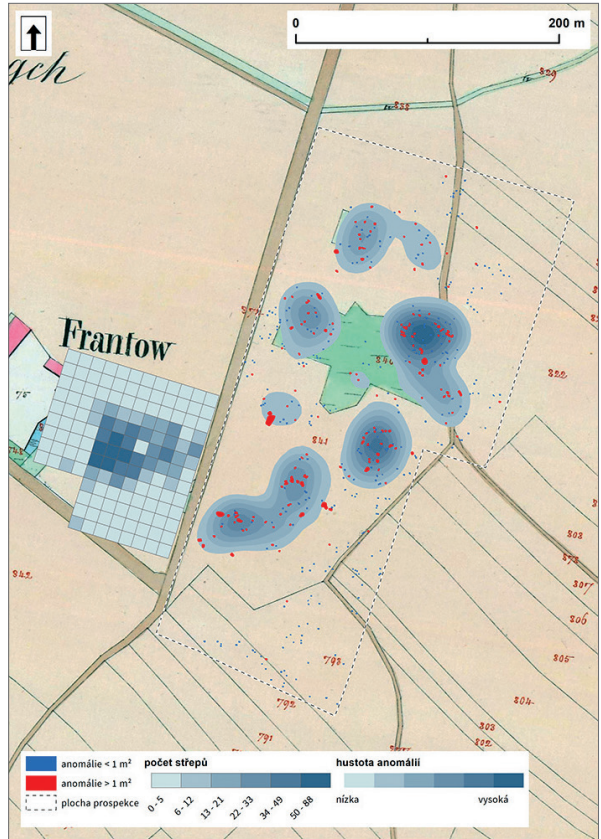

Obr. 7. Zaniklá vesnice Habřinka. Hustota geofyzikálně detekovaných archeologických objektů a sběrového materiálu na podkladu císařských otisků stabilního katastru. Zdroj ČÚZK.

Abb. 7. Dorfwüstung Habřinka. Dichte der geophysikalisch detektierten arachäologischen Objekte und des gesammelten Materials auf der Vorlage von kaiserlichen Abdrücken des Stabilen Katasters. Quelle Tschechisches Amt für Landesvermessung und Kataster. podobu/strukturu vrcholně středověké vesnice. Nemůžeme tak posoudit, zda absence kamenných konstrukcí vybočuje z obecného rámce, či nikoliv. Region středního Polabí se vyznačoval většinou prŕizemní a převážně roubenou architekturou až do 19. století (Štěpán-Vařeka 1991, 36-49). Absence kamenných struktur tak nemusí být u vesnice zaniklé na počátku 17 . století ničím neobvyklým. ${ }^{11}$

Na základě magnetometrického měření a prostorové distribuce keramiky můžeme odhadovat existenci sedmi až osmi struktur, které bychom mohli považovat za jednotlivé usedlosti. V písemných pramenech z rozmezí let 1521-1654 máme doložen provoz nejvíce šesti usedlostí. Tento rozpor by snad mohl být vysvětlen tím, že prospekce zachytila usedlosti, které již mohly být na počátku 16. století opuštěné. Pochopitelně lze navrhnout i možnost, že během existence vsi došlo k přesunu některých usedlostí mimo původní lokační prostor.

Jestliže uvažujeme, že intravilán Habřinky měl tvar dvoustranné návesní vsi, či komunikační vesnice návesního charakteru, mohl mít osové rozměry ca $350 \times 150 \mathrm{~m}$. Tento půdorys nevybočuje $\mathrm{z}$ dimenze a forem okolních sídel. Pakliže budeme vycházet z rozměrů intravilánů dle stabilního katastru, okolní vsi měly rozměry: Hořiněves ca $620 \times 160 \mathrm{~m}$ (půdorys hromadný návesní a komunikační), Lužany ca $330 \times 190$ m (půdorys komunikační), Račice ca $480 \times 210$ m (půdorys komunikační), Žíželeves ca $390 \times 290$ m (půdorys návesní).

11 Např́iklad během dlouholetého dozorování stavebních zásahů v intravilánech vsí na Královéhradecku nebyly doposud zachyceny kamenné struktury odpovídající vrcholně středověkému stáří. 


\section{Závěr}

Provoz vsi Habřinky můžeme sledovat na základě písemných pramenů. Po jejím zániku během první poloviny 17. století zůstaly stopy její existence vepsané do částí parcelního uspořádání na pozemkových mapách 19. století, stejně tak lze v archivních kartografických dílech sledovat změny ve vedení místní komunikační sítě cest. Důležité svědectví však přinesl nedestruktivní archeologický průzkum v podobě systematických povrchových sběrů a geofyzikálního průzkumu. Ačkoliv se plochy užití jednotlivých metod nepřekrývaly, výsledky obou průzkumů si vzájemně odpovídají, jejich kombinací se podařilo zachytit většinu osídleného areálu, ve kterém lze sledovat vnitřní strukturu.

V kontextu bádání o zaniklých vsích středověku a raného novověku nemají naše výsledky př́lišs srovnatelných paralel, nebot' výzkum se obecně zaměřuje zejména na lokality s dochovanými relikty. Jako přínosné se tedy jeví provést obdobné měření na dalších lokalitách umístěných v zemědělsky využívaném polním prostředí. Poté by se mohlo snáze dojít k zodpovězení otázek, zda absence kamenných struktur a zřetelněji definované zástavby u zaniklé Habřinky, kterou známe ze zaniklých sídlišt' umístěných v lesním prostředí, je výjimkou, či v prostředí (nejen) severovýchodních Čech běžnou záležitostí.

\section{Prameny}

AČ 1: Archiv český, čili staré písemné památky české i morawské Díl 1 (Palacký, F., ed.). Praha 1840.

AČ 4: Archiv český, čili staré písemné památky české i morawské Díl 4 (Palacký, F., ed.). Praha 1846.

AČ 16: Archiv český, čili staré písemné památky české i moravské Díl 16 (Kalousek, J., ed.). Praha 1897.

AČ 17: Archiv český, čili staré písemné památky české i moravské Díl 17 (Kalousek, J., ed.). Praha 1899.

BR 14: Berní rula 14. Kraj Hradecký III. (Čadková, I.-Zahradníková, M., edd.). Praha 2009.

LC I/1: Libri confirmationum ad beneficia ecclesiastica pragensem per archidioecesim I/1 1354-1362 (Tingl, Franciscus Antonius, ed.). Pragae 1867.

\section{Literatura}

BLÁHA, R., 1998: Osídlení Jaroměře do konce 13. století, ZMHK 24, 82-99.

- 2000: Keramika 10.-13. století v severovýchodních Čechách a její vztahy k okolním oblastem. Rkp. magisterské diplomové práce, ulož. na MU, Brno.

BLÁHA, R.-KALFERST, J.-SIGL, J., 2004: Přírůstky archeologické sbírky hradeckého muzea v letech 2000-2003, ZMHK 30 - Supplemnetum, 3-142.

BLÁHA, R.-SIGL, J., 2014: Počátky Pražského předměstí v Hradci Králové z pohledu archeologie, Forum urbes medii aevi 14, 132-151.

BLAŽKOVÁ, G., 2011: Hmotná kultura z Pražského hradu raného novověku ve světle archeologických nálezů. Rkp. disertační práce, ulož. na UK, Praha.

DOLEŽALOVÁ, K., 2015: Výzkum vrcholně a pozdně středověké keramiky na území České republiky se zaměřením na deskripční systémy a třídění keramiky podle technologie výroby, Acta Fakulty filozofické Západočeské univerzity v Plzni 7, č. 2, 39-66.

DOSKOČIL, K., 1953: Popis Čech r. 1654. Praha.

DRESLER, P.-TENCER, T.-VÁGNER, M., 2015: Prospekce zaniklé středověké vesnice Opatovice, k. ú. Hrušky, Studia archaeologica Brunensia E 20, 113-132.

DRESLER, P.-MILO, P.-TENCER, T.-VÁGNER, M.-DEJMAL, M., 2019: Nedestruktivní průzkum polních systémů a struktury zástavby zaniklé středověké vesnice Vojšice (okres Hodonín) - Zerstörungsfreie Untersuchung der Feldsysteme und der Bebauungsstruktur der mittelalterlich Dorfwüstung Vojšice, AH 44, 269-287. 
DRNOVSKÝ, P., 2005: Zaniklá vesnice Habřinka, ZMHK 31, 237-252.

- 2013: Středověké osídlení na horním toku řeky Bystřice. Ústí nad Orlicí.

- 2018: Hmotná kultura šlechtických sídel severovýchodních Čech: Každodennost ve středověku pohledem archeologie. Hradec Králové.

DUBICKÝ, P., 1958: Zaniklá ves Habřinka, Hradecký kraj 2, 171-176.

HAVRDA, J.-MATĚJKOVÁ, K., 2014: Hrnčíři ve středověké Praze. Výsledky výzkumu výrobních zařízení z Malé Strany v kontextu dosavadních poznatků - Töpfer im mittelalterlichen Prag: Ergebnisse einer Untersuchung von Produktionsanlagen von der Prager Kleinseite im Kontext der bisherigen Erkenntnisse, AH 39, 23-51.

HOFMAN, M., 2007: Ke strategii a organizace povstání na trčkovských panství roku 1628, Orlické Hory a Podorlicko 14, 285-298.

CHALUPA, A., 1958: Panství Smiřice a jeho poddaní v polovině 17. století, Hradecký kraj 2, 197-215.

JEŽEK, M., 2007: Jaroměřsko v raném středověku, AR LIX, 523-570. Praha.

KALFERST, J.-SIGL, J.-VOKOLEK, V., 1989: Archeologické nálezy získané v letech 1987-1988, ZMHK 16, 3-19.

- 1991-1992: Archeologické př́růstky v Muzeu východních Čech v Hradci Králové v letech 1990 a 1991, ZMHK 18, 7-29.

KLÁPŠTĚ, J., 1998: Die Anfänge der jüngeren mittelalterlichen Keramik in Böhmen als kulturhistorisches Problem, AR L, 138-158.

KLÍR, T., 2008: Osídlení zemědělsky marginálních půd v mladším středověku a raném novověku. Dissertationes Brunenses/Pragensesque 5. Praha - Brno.

KŘIVÁNEK, R., 2008: Př́iklady využití magnetometrických metod při průzkumech zalesněných archeologických lokalit. In: Ve službách archeologie 1 (Hašek, V.-Nekuda, R.-Ruttkay, M., edd.), 70-77. Brno.

KUNA, M., 2004: Povrchový sběr. In: Nedestruktivní archeologie (Kuna, M., ed.), 305-352. Praha.

KNAPP, A., 1887: Paměti královského věnného města Jaroměře nad Labem. Jaroměr.

MATĚJKOVÁ, K., 2014: Keramický sortiment turnovských domácností. Možnosti zpracování keramických souborů z městských stratigrafií - Das Keramiksortiment aus den Turnauer Haushalten: Bearbeitungsmöglichkeiten der aus Stadtschichten stammenden Keramikkollektionen, AH 39, 89-117.

PEROUTKOVÁ-MATĚJKOVÁ, K., 2008: Středověký a novověký Jičín ve světle archeologických nálezů a aspekt dobového hrnčířství. Rkp. magisterské diplomové práce, ulož. na MU, Brno.

PEŠTA, J., 2000: Několik poznámek ke studiu půdorysné struktury venkovských sídel na území Čech, PRP $8,153-168$.

REBITSCH, R., 2013: Matyáš Gallas: (1588-1647): císařský generál a Valdštejnův „dědic“. Praha.

ROUBÍK, F., 1959: Soupis a mapa zaniklých osad v Čechách. Praha.

SEDLÁČEK, A., 1882: Hrady, zámky a tvrze království českého. Díl 1. Chrudimsko. Praha.

- 1883: Hrady, zámky a tvrze království českého. Díl 2. Hradecko. Praha.

SCHALLER, J. F., 1790: Topographie des Königreichs Böhmen 15. Königgrazer Kreis. Wien.

SIGL, J.-VOKOLEK, V., 1986: Archeologické nálezy v roce 1985, ZMHK 13, 5-23.

SKALA, J.-BLÁHA, R., 2018: Středověký objekt z Roudnice, okr. Hradec Králové. Př́íspěvek k poznání vrcholně středověké keramiky, ASČ 22, 1005-1014.

ŠANDERA, M., 2016: Jindřich Starší z Minsterberka. Syn husitského krále. Velký hráč s nízkými kartami. Praha.

ŠTĚPÁN, L.-VAŘEKA, J., 1991: Klíč od domova. Lidové stavby východních Čech. Hradec Králové - Praha. VAŘEKA, P., 1998: Prameny keramické produkce vrcholného a pozdního středověku v Čechách, AR L, $123-137$.

VÍCH, D.-VOKOLEK, V., 1997: Nálezy získané do sbírek AO MVČ v letech 1996-97, ZMHK 23, 3-27.

WOLF, O., 2004: Keramika z manské tvrze v Mladých Bukách, ZMHK 30, 226-250.

- 2005: Počátky středověkého osídlení na česko-slezském pomezí východních Krkonoš. Rkp. disertační práce, ulož. na MU, Brno. 


\section{Zusammenfassung}

\section{Die mittelalterliche Dorfwüstung Habřinka bei Hořiněves (Bezirk Hradec Králové). Analyse und Interpretation der Oberflächensammlungen und geophysikalischen Messungen}

Der vorliegende Beitrag widmet sich der mittelalterlichen Dorfwüstung Habřinka, die sich in der Nähe von Hořiněves bei Hradec Králové in Ostböhmen befand. Anhand der schriftlichen Quellen lässt sich herleiten, dass Habřinka und die nahen umliegenden Dörfer in vorhussitischer Zeit zum Besitz des Klosters Opatovice gehörten. Aus der Zeit als Habřinka Bestandteil der östböhmischen Pernsteiner Besitzungen war, ist im Rahmen eines Pardubitzer Urbariums aus dem Jahr 1521 auch seine Beschreibung überliefert. Das Dorf gelangte insgesamt viermal in die Aufzeichnungen der Urbarien der Herrschaft von Schmiritz aus den Jahren 1588, 1619, 1642 und 1655. Dank ihnen kann man sich auch von der Größe Habřinkas und der Nachbardörfer eine Vorstellung machen. Zum Jahr 1588 werden vier Hintersassen aufgeführt, und zum Jahr 1610 dann sechs Wirtschafter. Im zum Jahr 1655 erstellten Schmiritzer Urbarium wird dann aufgeführt, dass das Dorf Kusá Habřinka völlig wüst ist, und dass die Ländereien und Wiesen vom Zizeloweser Hof und den Bewohnern von Ratschitz genutzt werden. In der Steuerrolle vom Jahr 1654 wird ebenfalls angegeben, dass Kusá Habřinka (vier Bauernhöfe und ein Häusler) völlig wüst ist, die Namen der Besitzer der einzelnen Höfe jedoch noch eingetragen sind. Auch als das Schmiritzer Dominium unter den Söhnen von Matthias Gallas aufgeteilt wurde, wird Habřinka als wüst und ohne Taxierung aufgeführt.

Gegenwärtig kann man die Lage der mittelalterlichen Dorfwüstung in der Mitte eines gedachten Kreises zuverlässig identifizieren, der von den Dörfern Račice nad Trotinou, Habřina, Lužany, Žíželeves, Vrchovnice und Hořiněves gebildet wird (Abb. 1). Habřinka wurde auf einer leicht flachen Anhöhe gegründet, die sich zwischen den oben aufgeführten Dörfern befindet. Höchster Punkt ist die westlich vom Frantov-Hof gelegene Kote von 267 m ü.N.N. Im Süden fällt die erwähnte Anhöhe fließend zum Frantov-Bach hin ab, der dann in den Fluss Trotina mündet, der in diesem Raum gleichzeitig der stärkste Wasserlauf ist.

Ziel der zerstörungsfreien Prospektionsmethoden war es, die angenommene Lokalisierung der Dorfwüstung zu verifizieren, ihren Umfang, die Topographie und die Anfänge, bzw. Gründung der Fundstelle anhand der entdeckten archäologischen Funde ggf. zu präzisieren.

Während Oberflächensammlungen wurden fast 1400 Keramikindividuen entdeckt, von denen die meisten zur Küchen- und Tafelkeramik zählen. Der Keramikkomplex wurde zwecks Feststellung der Grundmorphologien, Herstellungsverfahren und Verzierungen mit dem Ziel einer Deskription unterzogen, eine relative Chronologie der besiedelten Fundstelle zu erstellen. Wenn man die Auswertungsergebnisse des Keramikkomplexes zusammenfasst, lassen sich aus Sicht der Chronologie drei Grundhorizonte festlegen: 1) Keramik der älteren Periode des Hochmittelalters, 2) Keramik des Hochmittelalters, 3) spätmittelalterliche Keramik und Ware der frühen Neuzeit. Es ist keine Überraschung, dass die meisten Artefakte dem jüngsten chronologischen Horizont zugeordnet werden können, der aus Vertretern der Gruppe D und teilweise auch aus der Einheit der Keramikgruppe C besteht. Gruppe C selbst umfasst sowohl den hochmittelalterlichen, als auch den jüngeren Zeitraum. Eine Abgrenzung zwischen älterer und jüngerer hochmittelalterlicher Keramik ist schwierig.

Die an der angenommenen Lage der Dorfwüstung Habřinka durchgeführte geophysikalische Untersuchung erfolgte im Oktober 2018. Für die Untersuchung dieses Fundstellentyps wurde die Magnetometrie als die am besten geeignete Methode gewählt. Bei der magnetischen Prospektion wurden zahlreiche Anomalien festgestellt, die man als archäologisch relevante Objekte oder Strukturen interpretieren kann (Abb. 4, 5, 6). Trotz des unsicheren Ergebnisses der magnetischen Untersuchung, bei welcher die einzelnen Anomalien nicht als typische archäologische Objekte zum Vorschein kommen, kann man auf den Ergebniskarten eine Tendenz zur Bildung selbständiger Objektgruppen beobachten. Für diese ist das Vorhandensein einer größeren Anzahl an 
Objekten, von Strukturen größerer Abmessungen, aber hauptsächlich eines magnetisch positiven Hintergrundrauschens typisch, das wir als zerackerte Objekte und Schichten interpretieren. Sie deuten auf Stellen mit einer intensiveren Besiedelung und Bewirtschaftungsaktivitäten im Mittelalter hin, und wir können die einzelnen Wirtschaftshöfe dorthin lokalisieren. Insgesamt sind auf dem Magnetogramm sechs bis sieben von ihnen sichtbar. Am deutlichsten erkennbar sind die vier, die sich im nördlichen und zentralen Teil der Fläche befinden. Das kleinste Areal nimmt eine Fläche von nur ungefähr $500 \mathrm{~m}^{2}$ ein, das größte hat $3700 \mathrm{~m}^{2}$. Die restlichen Areale haben insgesamt vergleichbare Abmessungen mit Flächen zwischen $1600 \mathrm{~m}^{2}$ und $2600 \mathrm{~m}^{2}$. Der potenzielle Wirtschaftshof besteht aus zwei in Richtung Nordost-Südwest verlaufenden Reihen. Da weitere solche Strukturen im nördlichen Teil des Magnetogramms fehlen, kann man annehmen, dass sich weiter in diese Richtung keine ausgeprägtere Besiedelung befindet. Weitere ähnliche Strukturen könnte man westlich von der untersuchten Fläche annehmen. Anhand der Streuung des mittels Oberflächensammlungen gewonnenen Keramikmaterials kann man dort noch mindestens einen Wirtschaftshof erwarten. Die Fläche mit der größten Konzentration an arachäologischen Artefakten erreicht ca. $2500 \mathrm{~m}^{2}$, was voll und ganz dem Umfang der einzelnen, durch geophysikalische Untersuchung detektierten Anwesen entspricht. Die Lage des durch Oberflächensammlungen lokalisierten Anwesens korreliert darüberhinaus mit den mittels geophysikalischer Untersuchung gemachten Feststellungen. Das betreffende Anwesen befindet sich mit der westlichen Reihe der Anwesen in einer Linie und hat theoretisch deren Südrand bilden können. In dem gesamten Raum können wir somit sieben bis acht Objektanhäufungen / Sammelartefakte beobachten, die es uns dort ermöglichen, die gleiche Anzahl an Anwesen anzunehmen.

Mgr. Pavel Drnovský, Ph.D., Katedra archeologie Filozofické fakulty Univerzity Hradec Králové, Rokitanského 62, 50003 Hradec Králové, Česká republika, pavel.drnovsky@uhk.cz

doc. Dr. Peter Milo, Ústav archeologie a muzeologie Filozofické fakulty Masarykovy univerzity, Arna Nováka 1,60200 Brno, Česká republika,101090@mail.muni.cz

Mgr. Tomáš Tencer, Ph.D., Ústav archeologie a muzeologie Filozofické fakulty Masarykovy univerzity, Arna Nováka 1, 60200 Brno, Česká republika, tomastencer@seznam.cz 
